\title{
Standardisation Study of Kwatha Curnas
}

\author{
M. K. SANTOSH,* D. SHAILA and I. SANJEEVA RAO \\ Varun Herbals Pvt. Ltd., 5-8-293/A, \\ Mahesh nagar, Chirag ali lane, \\ Hyderabad- 500001
}

Received 9 August 2004; Accepted 10 Sep 2004

\begin{abstract}
The present paper deals with the standardization of kwatha curnas such as dhanyapanchak kwatha curna, guduchyadigana kwatha curna and stanyajanankashaya curna. These are the important Ayurvedic formulations used for peri-natal care of mother and child health. Standardization of kwatha curnas were achieved by physico-chemical analysis, qualitative inorganic and organic analysis, thin layer chromatography (TLC), UV- visible spectrophotometry and high performance liquid chromatographic (HPLC) fingerprint studies. TLC study of kwatha curnas was carried out in Ethyl acetate: Methanol: Water solvent system. Ethanol extracts of kwatha curnas were used for UV- visible spectrophotometry and qualitative HPLC fingerprint study.
\end{abstract}

Key words Standardization, Kwatha curnas, TLCand HPLC.

\section{Introduction}

Kwatha curnas are compound coarse powders, which are intended for usage whenever particular decoction is required. In the present paper, three-kwatha curnas viz., dhanyapachak kwatha curna, guduchyadigana kwatha curna and stanyajanana kashaya curna were selected for standardization study. These kw atha curnas are used for the perinatal care of mother and child health. Process standardization of kwatha curnas namely, arkadi kwatha, phalatrikadi kwatha and rasna saptaka kwatha curnas has been reported. According to the analytical data, TLC and organic qualitative analysis, the preparation by the second method (by individual pow dering of ingredients and compounding them in required proportion to get the final product) revealed more active principles ${ }^{1}$.

The clinical study of dhanyapanchak kashaya curna showed that this herbal drug has beneficial effect on dyspeptic symptoms ${ }^{2}$.

\section{Materials and Methods}

The authentic ingredients were procured from the local market of Hyderabad, Andhra Pradesh and were botanically identified. Dhanyapanchak kwatha curna, guduchyadigana kwatha curna and stanyajanana kashaya curna were prepared as per the procedure described in Ayurvedic Formulary of India ${ }^{3 \& 4}$. 
Analytical study

The prepared samples were analyzed for the parameters such as $\mathrm{pH}$ ( $1 \%$ aqueous), moisture content, total ash, acid insoluble ash, alcohol soluble extractive, water-soluble extractive, qualitative inorganic and organic analysis ${ }^{5 \& 6}$.

\section{Thin layer chromatography}

TLC plates were prepared as per the procedure described by Stahl ${ }^{7}$. The $4 \%$ alcoholic extracts of the samples were prepared by soaking them for $18 \mathrm{~h}$ in alcohol. Alcoholic extracts were filtered and about $100 \mu \mathrm{l}$ was loaded on the TLC plate and eluted in ethyl acetate: methanol: water (100:13.5:10) solvent system ${ }^{8}$. The plates were sprayed with vanillin-sulphuric acid reagent and the spots were detected after heating at $110^{\circ} \mathrm{C}$ for $30 \mathrm{~min}$. Rf value of each spot was calculated.

\section{Sample preparation}

The $4 \%$ alcoholic extracts of the samples were prepared by soaking them for $18 \mathrm{~h}$ in alcohol. The extracts were filtered through Whatman filter paper number 1 using high-pressure vacuum pump. The samples were used for UV- visible spectrophotometric and HPLC fingerprint study.

UV-visible spectrophotometric analysis

The samples were scanned over a range of 200-800nm using EUCO (SL-159) UV-visible spectrophotometer equipped with quartz cuvettes of $10 \mathrm{~mm}$ path length and UV-visible spectrasoft software. Alcohol was used as a reference.

\section{HPLC analysis}

A gradient HPLC (Shimadzu HPLC Cass VP series) with two LC- 10 AT VP pumps (Shimadzu), variable wavelength programmable photo diode array detector SPD-M10A VP (Shimadzu), CTO-10AS VP column oven (Shimadzu), SC-10A VP system controller (Shimadzu) and reverse phase Luna $5 \mu C_{18}$ (2) Phenomenex column $(250 \mathrm{~mm} \times 4.6 \mathrm{~mm})$ was used. The HPLC system was equipped with software Class VP series version 6.1 (Shimadzu). The mobile phase components methanol: water were filtered through $0.2 \mu$ membrane filter before use and pumped from the solvent reservoir to the column at a flow rate of $1 \mathrm{ml} / \mathrm{min}$ which yielded a column back pressure of $220 \mathrm{kgf} / \mathrm{cm}^{2}$. The column temperature was maintained at $27^{\circ} \mathrm{C} .20 \mu \mathrm{l}$ of sample was injected by using Rheodyne syringe (Model 7202, Hamilton).

\section{Results and Discussion}

The data of physico-chemical analysis of dhanyapanchak kwatha curna, guduchyadigana kwatha curna and stanyajanana kashaya curna is summarized in Table-1. The data of qualitative inorganic and organic analysis of kwatha curnas is summarized in Table-2. The data of TLC study of kwatha curnas is summarized in Table-3. The UV-visible spectrophotometric data of kwatha curnas is tabulated in Table-4.

Table 1. Analytical data of kwatha curnas

\begin{tabular}{|c|c|c|c|c|}
\hline S. No. & $\begin{array}{l}\text { Analytical } \\
\text { Parameters }\end{array}$ & $\begin{array}{l}\text { Dhanyapanchak } \\
\text { kwatha curna }\end{array}$ & $\begin{array}{l}\text { Guducyadigana } \\
\text { kwatha curna }\end{array}$ & $\begin{array}{r}\text { Stanyajanana } \\
\text { kwatha curna }\end{array}$ \\
\hline 1. & $\mathrm{pH}$ ( $1 \%$ aqueous) & 5.02 & 5.77 & 6.26 \\
\hline 2. & Moisture (\%) & 8.08 & 6.65 & 6.7 \\
\hline 3. & Total ash (\%) & 7.11 & 7.92 & 18 \\
\hline 4. & $\begin{array}{c}\text { Acid insoluble (\%) } \\
\text { ash }\end{array}$ & 2.03 & 0.17 & 10.65 \\
\hline 5. & $\begin{array}{l}\text { Alcohol soluble } \\
\text { extractive (\%) }\end{array}$ & 7.65 & 6.15 & 3.5 \\
\hline 6. & $\begin{array}{l}\text { Water soluble } \\
\text { extractive (\%) }\end{array}$ & 13.55 & 6.1 & 4.5 \\
\hline
\end{tabular}


Table 2. Qualitative inorganic and orgarinc analytical data of kwatha curnas

\begin{tabular}{|c|c|c|c|c|}
\hline S. No. & $\begin{array}{l}\text { Analytical } \\
\text { Parameters }\end{array}$ & $\begin{array}{l}\text { Dhanyapanchak } \\
\text { kwatha curna }\end{array}$ & $\begin{array}{l}\text { Guducyadigana } \\
\text { kwatha curna }\end{array}$ & $\begin{array}{l}\text { Stanyajanana } \\
\text { kwatha curna }\end{array}$ \\
\hline 1. & Calcium & tve & tve & tve \\
\hline 2. & Magnesium & tve & tve & tve \\
\hline 3. & Iron & tve & tve & tve \\
\hline 4. & Aluminum & -ve & -ve & tve \\
\hline 5. & Lead & -ve & -ve & -ve \\
\hline 6. & Arsenic & -ve & -ve & -ve \\
\hline 7. & Mercury & -ve & -ve & -ve \\
\hline 8. & Alkaloids & tve & tve & -ve \\
\hline 9. & Steroids & tve & tve & -ve \\
\hline 10. & Phenols & tve & tve & tve \\
\hline 11. & Tannins & tve & tve & tve \\
\hline 12. & Glycosides & tve & tve & tve \\
\hline 13. & Resins & tve & tve & tve \\
\hline 14. & Saponins & tve & tve & tve \\
\hline 15. & Flavonoids & tve & tve & -ve \\
\hline
\end{tabular}

Table 3. Data of TLC study of kwatha curnas

$\begin{array}{cccc}\text { S. No. } & \begin{array}{c}\text { Dhanyapanchak } \\ \text { kwatha curna } \\ \text { Rf value (color) }\end{array} & \begin{array}{c}\text { Guducyadigana } \\ \text { kwatha curna } \\ \text { Rf value (color) }\end{array} & \begin{array}{c}\text { Stanyajanana } \\ \text { kwatha curna } \\ \text { Rf value (color) }\end{array} \\ \text { 1. } & 0.07(\mathrm{BG}) & 0.08(\mathrm{BG}) & 0.07(\mathrm{BG}) \\ 2 . & 0.17(\mathrm{LBG}) & 0.19(\mathrm{LBG}) & 0.22(\mathrm{LBG}) \\ 3 . & 0.24(\mathrm{BG}) & 0.25(\mathrm{LBG}) & 0.30(\mathrm{LBG}) \\ 4 . & 0.97(\mathrm{~V}) & 0.97(\mathrm{~V}) & 0.97(\mathrm{~V})\end{array}$

Where, V- Violet, $\mathrm{BG}$ - Blue Green, $\overline{\mathrm{LBG}}$ - Light Blue Green

Table 4. Data of UV-Visisble Spectrophotometric study of Kwatha Curnas

\begin{tabular}{|c|c|c|c|c|c|}
\hline \multirow[t]{2}{*}{ S. No. } & \multicolumn{2}{|c|}{$\begin{array}{l}\text { Dhanyapanchak } \\
\text { kwatha curna }\end{array}$} & \multicolumn{2}{|c|}{$\begin{array}{l}\text { Guducyadigana } \\
\text { kwatha curna }\end{array}$} & \multirow{2}{*}{$\begin{array}{l}\text { Stanyajanana } \\
\text { kwatha curna } \\
\text { W.L. O.D. } \\
(\mathrm{nm})\end{array}$} \\
\hline & $\begin{array}{l}\text { W.L } \\
(\mathrm{nm})\end{array}$ & O.D. & $\begin{array}{l}\text { W.L. } \\
(\mathrm{nm})\end{array}$ & O.D. & \\
\hline 1 & 265 & 2.799 & 270 & 2.686 & $297 \quad 2.670$ \\
\hline 2 & 300 & 2.829 & 299 & 2.716 & \\
\hline 3 & 464 & 3.088 & 390 & 2.102 & \\
\hline 4 & 489 & 3.268 & & & \\
\hline 5 & 664 & 0.283 & & & \\
\hline
\end{tabular}

The qualitative HPLC fingerprint profiles of dhanyapanchak kwatha curna, guduchyadigana kwatha curna and stanyajanana kashaya curna are shown in Figure - 1 to 3 respectively. The HPLC chromatogram of dhanyapanchak kwatha curna showed three prominent peaks at a retention time of 
2.763min, 3.328min and 24.245min with an area percentage of 27.55, 6.17 and 24.36. The HPLC chromatogram of guduchyadigana kwatha curna showed three prominent peaks at a retention time of $2.848 \mathrm{~min}, 3.328 \mathrm{~min}$ and $22.603 \mathrm{~min}$ with an area percentage of $46.77,13.24$ and 13.86 . The HPLC chromatogram of stanyajanana kashaya curna showed ten prominent peaks at a retention time of $2.880 \mathrm{~min}, 3.339 \mathrm{~min}, 6.816 \mathrm{~min}, 13.621 \mathrm{~min}, 15.477 \mathrm{~min}, 17.291 \mathrm{~min}, 18.069 \mathrm{~min}, 25.013 \mathrm{~min}, 28.555 \mathrm{~min}$ and $29.323 \mathrm{~min}$ with an area percentage of $2.57,9.03,3.72,2.99,3.19,2.48,3.09,11.74,1.97$ and 1.27 .

Figure 1. HPLCChromatogram of Dhanyapanchak Kwatha Curna

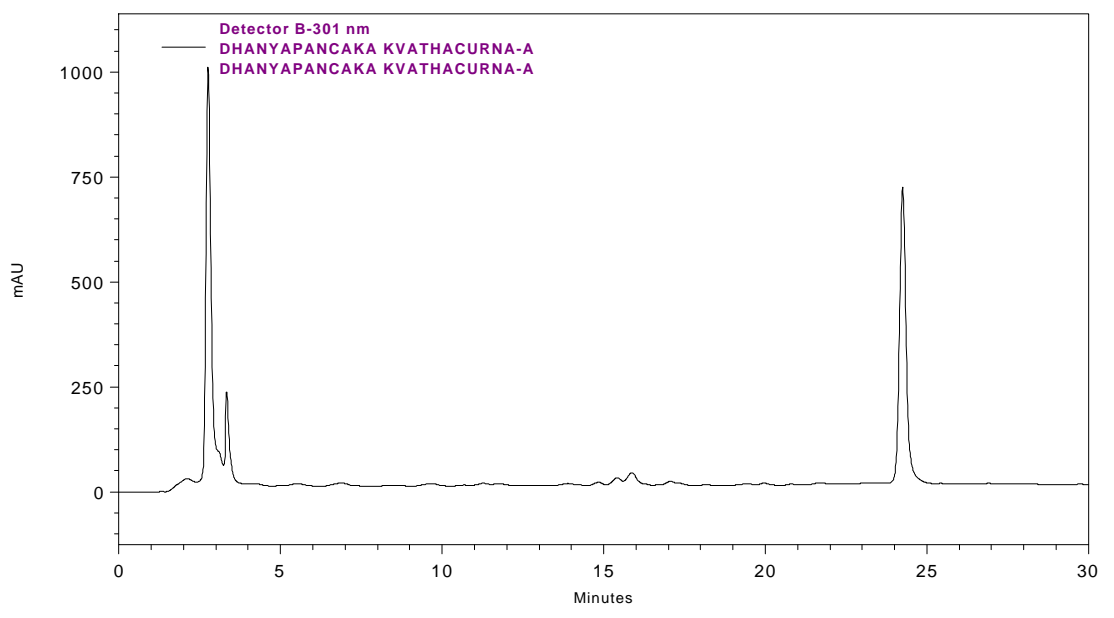

Figure 2. HPLC Chromatogram of Guduchyandigana Kw atha Curna

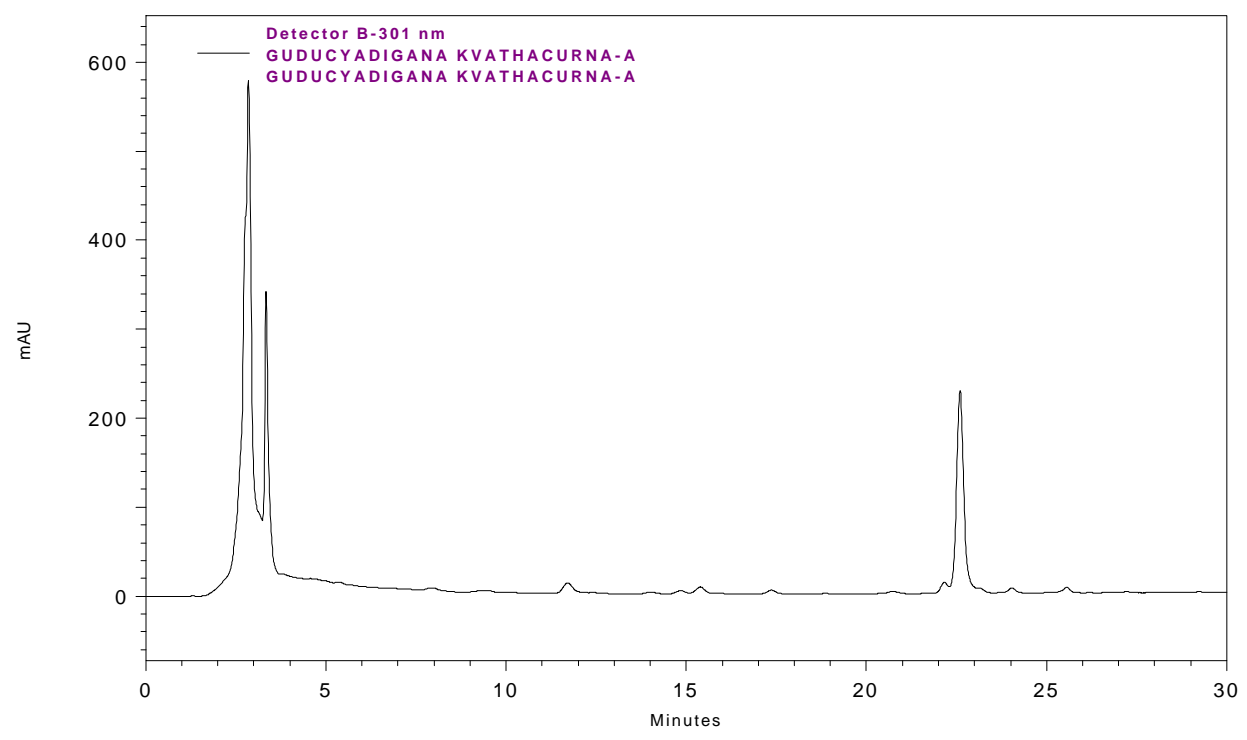


Figure 3. HPLC Chromatogram of Stanyajanana Kashaya Curna

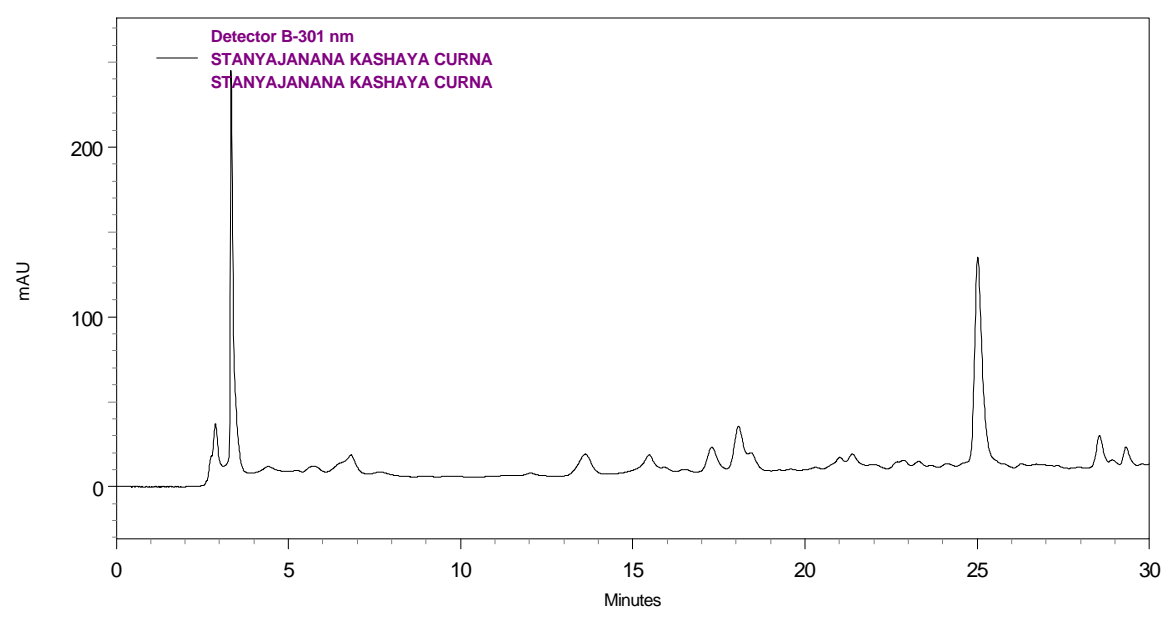

\section{Conclusion}

The analytical data, TLC, UV-visible spectrophotometric and HPLC fingerprint profiles evolved can be considered as viable parameters which will go a long way for prescribing a dependable standards to these preparations.

\section{Acknowledgement}

The authors are thankful to the Secretary, Department of RCH, Ministry of Health and Family Welfare, New Delhi, for providing financial support.

\section{References}

1. Meenakshi Natarajan, Rukmani Sundaresan, Pappa Pandiyan, Shanmugadasan K K d Muzaffer Alam and Bhima Rao, R. J R A S 1979, 10(1-2), 62.

2. Tripathi SV, Sachitra Ayurved, 1985, 37(9), 549.

3. Ayurvedic Formulary of India, Department of ISM\&H, Ministry of Health and Family Welfare: New Delhi, 1978; Part- I.

4. Ayurvedic Formulary of India, Department of ISM\&H, Ministry of Health and Family Welfare: New Delhi, 2000; Part- II.

5. Quality control methods for medicinal plant materials, World Health Organization, Geneva, 1998.

6. Kulkarni P H and Apte B K, Research Methodology for Students of Ayurveda; Ayurveda Research Institute: Pune, 2000.

7. Stahl E, Thin Layer Chromatography; George Allen and Unwin Ltd.: London, 1969.

8. Wagner H, Sabine Bladt, Plant drug analysis; $2^{\text {nd }}$ ed.; Springer- Verlag: Heidelberg, Germany, 1996. 


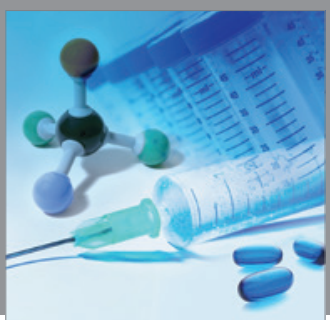

International Journal of

Medicinal Chemistry

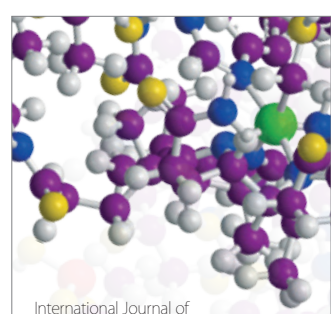

Carbohydrate Chemistry

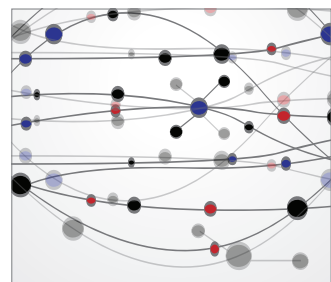

The Scientific World Journal
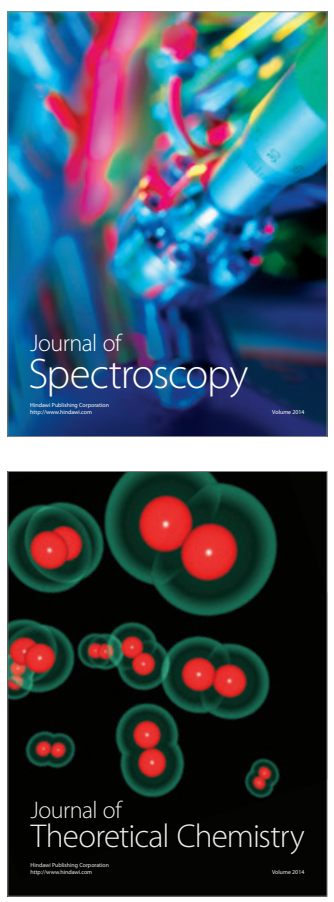
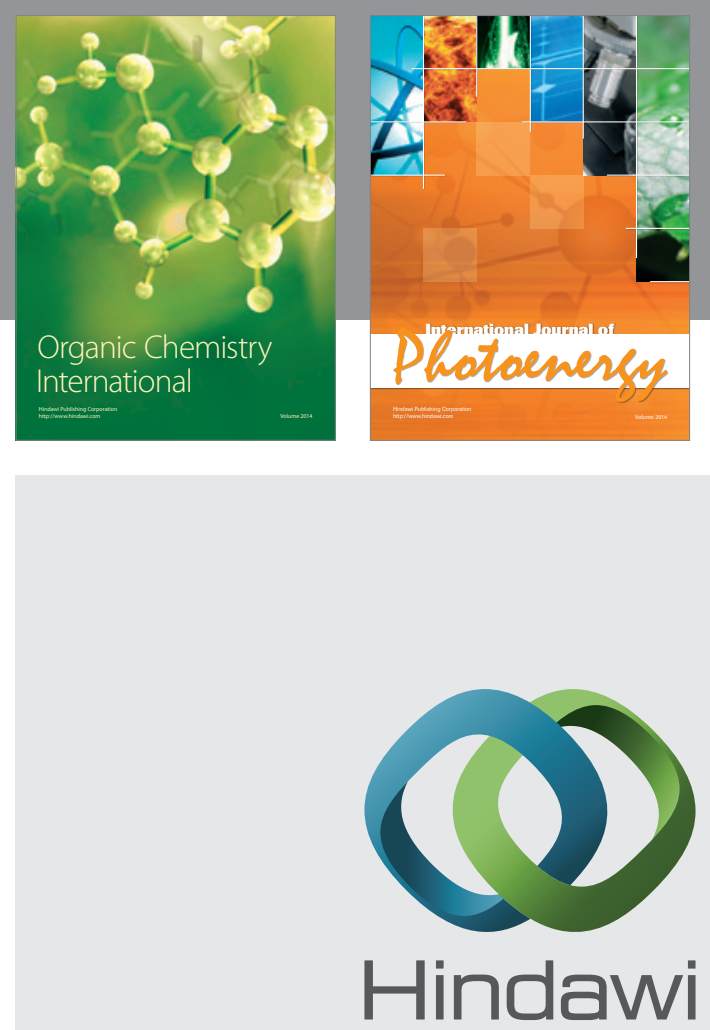

Submit your manuscripts at

http://www.hindawi.com
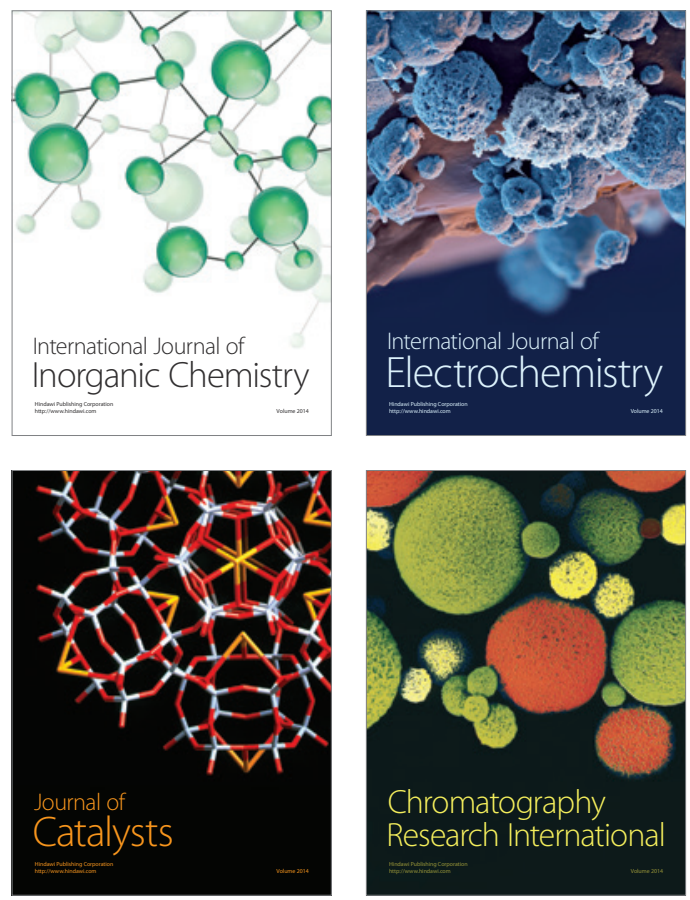
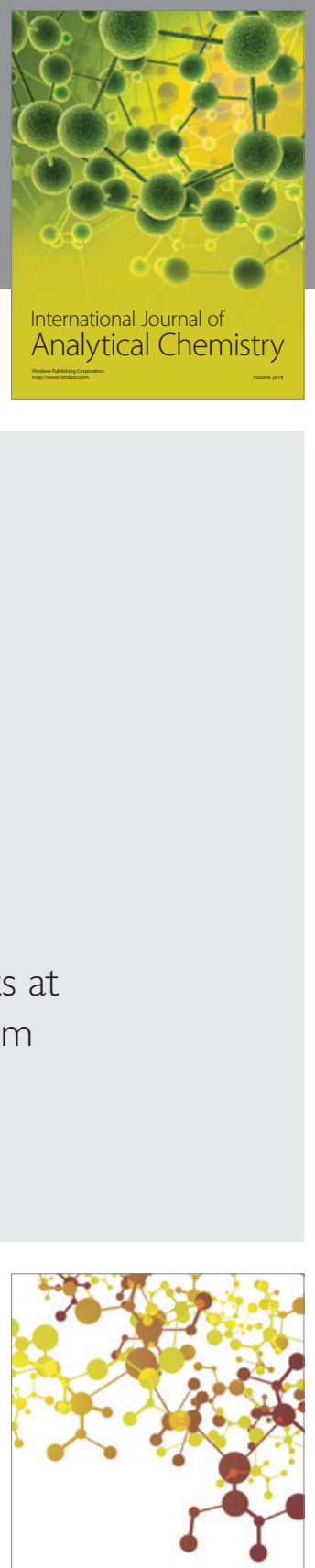

Journal of

Applied Chemistry
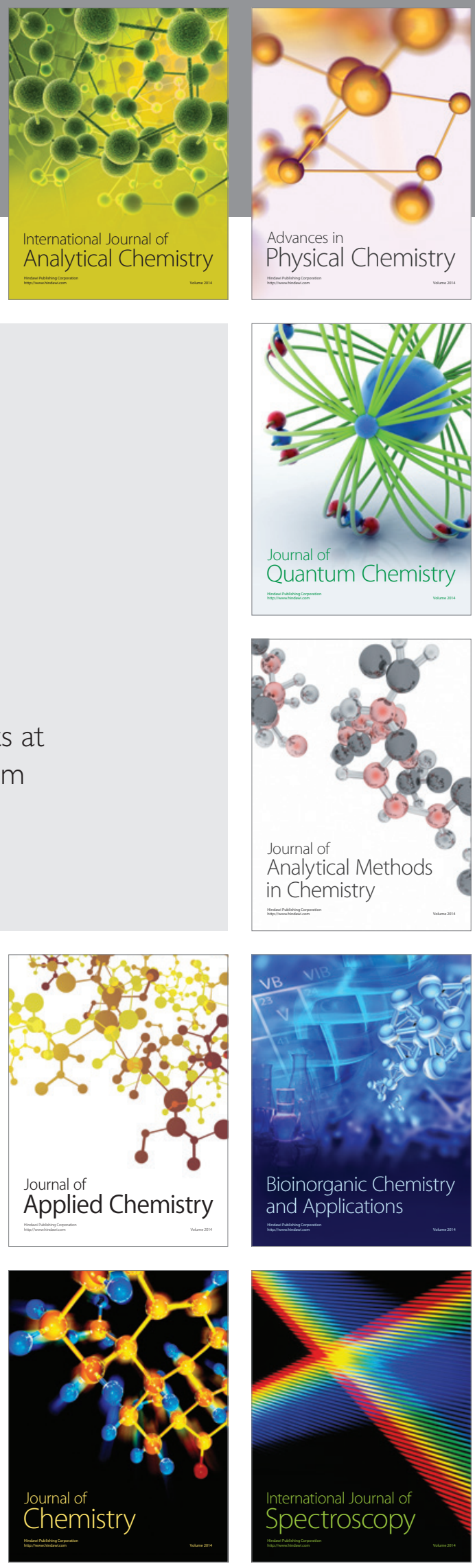